\title{
RICARDO PIGLIA COMO FACTÓTUM IMPURO DE LA MODERNIDAD LITERARIA: ENSAYOS Y DIARIOS DE UN AUTOR
}

\author{
Alfredo Aranda Silva \\ (University of Wisconsin Eau Claire)
}

\begin{abstract}
Siempre supe que el mejor modo de vivir era inventando un personaje y vivir de acuerdo con él. Si se ha elegido bien, hay una respuesta preparada para cada situación. Como alguien que habla una lengua extranjera que nadie conoce y espera por azar encontrar a un coterráneo con el que se pueda conversar. Hay que elegir el amor de acuerdo con cierto modo imaginario de vivir la vida (y no al revés). ¿Y no sería eso la felicidad? [Piglia, 2015b: 252].
\end{abstract}

Ricardo Piglia, Fin de junio, 1966 (Los diarios de Emilio Renzi * Años de formación, 2015).

Si algo me individualiza y sostiene mi concepción de la literatura, mi marca personal, es que nunca he tenido -ni he pretendido tenerun lugar mío (o propio), vivo en hoteles, en pensiones, en casas de amigos, siempre de paso, porque ése es para mí el estado de la literatura: no hay lugar propio, ni hay propiedad privada. Se escribe, digo yo cómicamente, desde ahí. Hombre de ningún lugar. [...] Miro críticamente ciertas decisiones de mi vida que fueron tomadas en función del futuro de mi literatura. Por ejemplo, vivir sin nada, sin propiedades, sin nada material que me ate y me obligue. Para mí elegir es desechar, dejar de lado. Ese tipo de vida define mi estilo, despojado, veloz. Hay que tratar de ser rápido y estar dispuesto siempre a dejar todo y escapar [Piglia, 2015b: 271 y 300]. 


\section{El "caso Piglia" en el contexto de la modernidad literaria}

La modernidad emerge de manera regular en el discurso intelectual porque posee como rasgo más comprensivo el hecho de ser una realidad conceptual en crisis permanente. Lejos de ser una realidad enteramente definida, se caracteriza por estar sometida al incesante proceso de hacerse y deshacerse, "siempre en cuestionamiento de sí misma, al extremo incluso de su propia desaparición y extinción, pero sin llegar nunca a desvanecerse por completo como el horizonte intelectual más abarcador del discurso actual." [Navajas 2004:116]. A pesar de su omnipresencia, ni la modernidad ni lo moderno constituyen [al decir de Habermas] "un hogar intelectual o un espacio protector en el que ubicarse con comodidad de manera estable y prolongada [...] La crisis constituye intrínsecamente el concepto [en la modernidad], lo hace ser de modo más auténtico y definidor." [ibid., 116]. En suma -concluye Gonzalo Navajas-, la modernidad no sería tanto una entidad sólida ni cabalmente cumplida, externa a la persona que observa, cuanto internalizada y en simultáneo desarrollo ${ }^{1}$ con la evolución de su conciencia como prolongación de sus propias vacilaciones y crisis ${ }^{2}$. No resulta extraño, pues, que estemos en este momento volviendo sobre la modernidad ${ }^{3}$, probablemente con los réditos y repliegues arbitrados por la modernidad europea como heráldica literaria de mayor y cíclica referencialidad, cuando todavía el cuitado debate sobre la posmodernidad continúa generando o recibiendo sus acólitos.

En razón del acervo de procesos estéticos, técnicos y sociológicos que tienen lugar a comienzos del siglo XX en el seno de la cultura europea, hablamos de una modernidad que, con todas las irregularidades que se quieran aducir, se consuma -se "restituye", han dicho con acierto Gracia y Ródenas [2011]- en el caso de España durante los años de la Segunda República, y se localiza en relación a su especificidad hispanoamericana durante los dos ciclos de modernización operados en el subcontinente americano tanto a principios del siglo XX como en la posterior década de los años 60, momento este último en el que comenzará a publicar precisamente su obra Ricardo Piglia.

\footnotetext{
${ }^{1}$ El origen de la palabra moderno es anterior al Renacimiento, remitiendo en su punto más lejano al siglo $\vee$ y registrándose más tarde -ya ampliamente utilizada- desde el siglo X por oposición a "antiguo, viejo, previo" [Calinescu 1987:23]. Modernus significaba "aquí y ahora, nuevo, presente", si bien el concepto tal y como lo conocemos hoy queda establecido solo a partir de la llustración francesa y en razón de la disputa entre anciens y modernes - The Battle of the Books en Inglaterra, según el homónimo texto de Jonathan Swift- a partir de la querelle que enfrentó a fines del siglo XVII a los antiguos con los modernos: "El proceso de la experiencia estética en la historia de la literatura y el arte europeos está siempre ordenado por una estructura temporal que, frente a toda metafísica del reconocimiento, establece, como dice Adorno «el carácter exclusivo de lo que es primero", y, con ello, el derecho de lo nuevo a negar lo viejo, segregándolo del canon del pasado." [Jauss 1995:65].

${ }^{2}$ Crisis que deviene "[...] metódica y preceptiva, elegida deliberadamente como procedimiento para prevenir la posibilidad de un hermetismo cognitivo exclusivizante." [Navajas, op. cit., 117].

${ }^{3}$ Véase, v. gr., la introducción de Mainer a su estudio dedicado a Alma contemporánea (1899), de Llanas Aguilaniedo [Mainer, en Cardwell y McGuirk 1993:147-149].
} 
El emplazamiento de la modernidad literaria hispanoamericana en sus dos ciclos de modernización se corresponderá tanto con una vibración crítica e interiorizada -aplicada, en aras de una serie de planteamientos y búsquedas preponderantemente identitarios, sobre su propio sustrato cultural- como con un deseo de distorsión mundana y renovación estética balizado por una mirada europeísta nada ajena a los procesos políticos y económicos acontecidos en el viejo continente.

Resulta especialmente pertinente fijarse en "el caso Piglia" en relación a todo vislumbre de modernidad literaria que se quiera hacer comparecer porque su escritura ha descrito, como pocas, el movimiento de un simultáneo desarrollo entre distintos géneros desde concepciones literarias y cuestionamientos propios a la vez que ha situado las acciones de la lectura y la escritura en el centro crítico y discursivo de todo su proyecto literario. La escritura de Piglia es la que hace de la entidad de autor un personaje inventado que, al mismo tiempo, establece por obra y gracia de la figuración literaria la medida de la vida. Estamos ante una escritura que, lejos de pretender posesionarse de nada, busca determinarse en la naturaleza desconocida de los lugares, imprimiendo en la materia histórico-literaria sobre la que se sitúa su eje referencial un gesto de permanente provisionalidad, de supervivencia y controversia.

Como le ocurre a la modernidad que acabamos de ver desde Habermas, también la visión pigliana de los hechos y los productos literarios carece de un hogar intelectual o dimensión benefactora en los que constituirse. De aquí que la escritura de Piglia genere una estructura de impureza o de rastros descentrados supeditada a una sospecha sistemática sobre sí misma, legitimando con ello no solo la tasa de modernidad que le es propia sino todo un entramado de vasos comunicantes en los que las acciones de leer y escribir se entronizan, a la vez que se atomizan, desde cierta reversibilidad ilimitada en torno a los actos de criticar y ficcionalizar. La concreción de modernidad literaria personalizada por Piglia se adscribe, por último, de modo prácticamente misional, a aquella idea de Borges acerca del amplio margen de libertad del que se ven provistas las literaturas periféricas a la hora de militar en una recepción irreverente de la tradición ${ }^{4}$.

Si bien uno de los atributos más reconocibles de la literatura de Piglia estriba en el hecho de inyectar materia ensayística en su narrativa, el ensayismo propiamente dicho del autor, escoltado

\footnotetext{
${ }^{4}$ En palabras del propio Piglia, tal y como leemos en su ensayo “¿Existe la novela argentina?" (1986), la tesis central de Borges en "El escritor argentino y la tradición" (1953) podría sintetizarse en el hecho de que "[...] las literaturas secundarias y marginales, desplazadas de las grandes corrientes europeas, tienen la posibilidad de un manejo propio, 'irreverente', de las grandes tradiciones. Borges pone como ejemplo de esta colocación, junto con la literatura argentina, a la cultura judía y a la cultura irlandesa. Sin duda, podríamos agregar en esa lista a la literatura polaca y en especial a Gombrowicz." [Piglia 2000:36]. Dicho a grandes rasgos, más allá de Borges y por circunscribirnos brevemente al ámbito argentino, la modernidad de Piglia vendría precedida por muy distintos paradigmas, desde Lugones, Quiroga, Arlt, Girondo o Macedonio hasta Güiraldes, González Tuñón, Nicolás Olivari, Juan L. Ortiz, Conti, Walsh, Wilcock, Cortázar o Antonio Di Benedetto, entre muchos otros.
} 
durante casi seis décadas de trayectoria literaria por toda una transversal labor multicultural, remite a la parte de su obra de la que aquí nos ocuparemos preponderantemente. Y ello no solo porque con la reciente publicación de los diarios de Piglia hayamos asistido a una destacada facturación de la modernidad literaria en relación a la práctica de la crítica y el ensayo sino porque, en el ámbito crítico y académico, se ha dado normalmente más cancha a las novelas del autor que a sus ensayos cuando hay al menos tanto -si no más, en ocasiones- que decir de los segundos como de las primeras. De hecho, cuando Piglia, como el prosista de ideas y renovador ensayista que es, comience a desenvolverse como crítico literario no hará sino -por utilizar sus propias palabras- reconstruir su vida "en el interior de los textos" que lee, apuntando ahí una noción de la modernidad literaria que ya nunca se disociará de su obra y que, desde las estrategias semánticas de la impureza y la transmutación, canalizarán el ejercicio crítico en Piglia -con reminiscencias que podrían llevarnos desde Gide y Freud hasta Barthes o Benjamin- hacia una de las formas posibles de la autobiografía No solo Piglia será entonces saludado como un lúcido integrante de la modernidad aventurada en lengua española sino que su contribución, como juez y parte, a la determinación del estatuto de dicha modernidad se tornará con el tiempo tan plural como manifiesta.

Entre otros, estos rasgos de impureza, provisionalidad, figuración y transmutación a los que me he referido son los que, desde los años sesenta, conducen a Piglia a una lectura descarada o a contramano de la tradición, fijándose en figuras entonces relativamente marginales de la modernidad hispánica (pensemos en Roberto Arlt o Macedonio Fernández, por ejemplo) para restituirles poco menos que una categorización de clásicos contemporáneos, a la vez que estableciendo con ellos, por vía de la afinidad espiritual, un orden de contigüidades e intersecciones críticas notablemente operativo. Por lo demás, el ensayo de Piglia puede derivar un tanto indefinidamente-sería, en parte, el caso de sus diarios- hacia un mecanismo de aspiración ficcional que, sin embargo, no parte siempre de situaciones nacidas consciente o necesariamente como expresiones y correlatos narrativos sino, más bien, como difusas irisaciones autobiográficas, entre mistificadas y reflexivamente introspectivas, que se disuelven finalmente en escenas literarias replicadas en torno al pozo sin fondo de Emilio Renzi ${ }^{6}$.

\footnotetext{
${ }^{5}$ En Crítica y ficción (1986), obra en la que se recopilan en un mismo volumen y por primera vez -a través de artículos, ensayos y entrevistas- las ideas literarias más importantes de Piglia, podemos leer: "El crítico es aquel que reconstruye su vida en el interior de los textos que lee" [Piglia 2001a:11]. Rodríguez Pérsico se ha referido a este aspecto de Piglia partiendo de la ascendencia de Borges: "Para Borges, toda literatura es autobiográfica; Piglia cree que el crítico comparte esa experiencia resultando un autobiógrafo que imagina su vida mientras piensa los textos que son objetos de su quehacer. [...] Piglia se aferra a la idea de que la literatura organiza la experiencia y da forma a lo informe y, al igual que Sarmiento, la piensa como espacio de lo heterogéneo: 'El que escribe no puede hablar de sí mismo. El que escribe solo puede hablar de su padre o de sus padres y de sus abuelos, de sus parentescos y genealogías', dice (Piglia 1998:15)." [Rodríguez Pérsico, 2017: 60-61].

6 "'He entrado en la literatura cuando he podido sustituir el «él» por el «yo»', Kafka. En mi caso podría decir: he entrado en mi autobiografía cuando he podido vivir en tercera persona." [Piglia 2015b:189].
} 
Por último, el papel de factótum cultural de la modernidad literaria queda progresivamente decretado en favor de Piglia desde finales de los años sesenta cuando, a su instinto y talento natural como crítico y cuentista junto a su aparición en el ámbito universitario, editorial, social y políticocultural, se van adhiriendo aspectos de su formación personal tales como una prolija familiaridad con la mayor parte de la producción cultural moderna escrita en español, un conocimiento superlativo de la literatura estadounidense contemporánea, un precoz apasionamiento por la novela policial canónica y periférica, un concienzudo estudio de las figuras mayores del modernismo europeo y una predilección última por la historia, el psicoanálisis, la filosofía del lenguaje y el pensamiento marxista.

\section{La traducción como clave ensayística de la modernidad}

De las muchas siluetas estratégicas -editor, compilador, antólogo, novelista, lector, copista, profesor de literatura, conferenciante, entrevistador y entrevistado, guionista de cine y crítico, entre otras- que podrían recortar con valor multidisciplinar la especificidad del influjo de Piglia en la sociedad de su tiempo, me fijaré a continuación en la labor traductora, aspecto de la esfera cultural que interesó a Piglia desde muy pronto ${ }^{7}$ y sobre el que ha escrito ensayos clarividentes. Y es que con las profesiones que acabamos de citar no solo estamos pensando en espacios prácticos de la cultura que se superponen o complementan en su desarrollo a través de terrenos fronterizos, atentando saludablemente contra la categorización -en ocasiones, aparentemente insalvable- de los componentes formativos de una trayectoria literaria dada sino que, en efecto, todos estos oficios representan alguna escena de trascendencia y veracidad en la vida personal, y en la mayor parte de los casos también profesional, de Piglia. He aquí reiterada, en su naturaleza última, ese carácter de factótum impuro de nuestra modernidad literaria tan airosamente personificado por Piglia.

Desde luego, en el traductor, que explota su sigilosa relevancia durante la modernidad y que se cuestiona a sí mismo siempre en relación a un original que siente como verdad jerárquica, encuentra Piglia la "impureza" del relegado que construye su trabajo en los márgenes del reconocimiento, que está hoy incluso suplantado por traductores automáticos en la red y en el que todavía se repara muy circunstancialmente a pesar de su relevancia en el entramado de la cultura escrita. El traductor escribe una obra sobre otra, "borrando" la fuente textual para el lector que no lee la lengua original de la obra

\footnotetext{
7 En fecha 21/02/1967, por ejemplo, Piglia anota en su diario que le ha propuesto al editor Jorge Álvarez traducir In Our Time (Three Mountains Press, 1924), el libro de Hemingway que no estaba entonces todavía traducido al español [cfr., Piglia 2015b:293].
} 
traducida. Literalmente, el traductor clausura realidades, decide la provisión de mundos alternativos. Por otra parte, el traductor es la figura literaria en la que se concentra la bipolaridad creativa del lector-escritor, es el intermediador ambivalente y creativo entre ambos hasta el punto de mejorar, en ocasiones, la comprensión del original ${ }^{8}$. Uno de los traductores de Piglia a la lengua inglesa, Sergio Waisman -el otro fue Daniel Balderston, traductor, por ejemplo, de Respiración artificial (1980) en 1994-, ha reflexionado acertadamente sobre la experiencia del traductor opinando como sigue:

[...] Una traducción es un texto que es más que un texto, una traducción es el propio texto y el otro texto al cual alude constantemente. [...] un arte de querer ser otro para así convertirse en uno mismo [...] Se trata de una invisibilidad que se hace visible en lo que no se revela, de un silencio que se escucha en el sonido que no se hace, escrito entre líneas, entre lenguas y culturas [...] en el momento de traducir, uno habita dos lenguas, y dos identidades, aunque sea momentánea e inestablemente. En este sentido, traducir es pluralizarse. Ser más de uno es incómodo y creo que así debería ser; es incómodo, difícil y precario, situarse en la frontera, en el límite, de las transformaciones necesarias creadas por la traducción (Waisman, en Romero, 2015: 89-90).

En un encuentro mantenido en 1998 en Berkeley entre Balderston, Waisman y Piglia dijo este último algo tan significativo como que "[...] A mí siempre me ha interesado la relación que hay entre la traducción y la propiedad, porque el traductor escribe todo un texto de nuevo que es de él, pero no es de él. Es una figura extraña la del traductor, está entre el plagio y la cita. La traducción es un extraño ejercicio de apropiación." [Piglia, en Romero 2015:90]. Por último, en referencia al ensayo de Borges "La supersticiosa ética del lector" [Borges 1931: 11-14] ${ }^{9}$, nos recuerda Waisman cómo Borges dio cuenta de los libros que sobreviven a sus peores traducciones, ejemplificándolo en El Quijote, una obra que en opinión de Borges ganaba batallas póstumas contra sus traductores ${ }^{10}$; es lo que Waisman ha denominado en Borges y la traducción. La irreverencia de la periferia (2005) el desarrollo de una teoría de la mala traducción desde los márgenes, una teoría en la que se desafían muchos de los conceptos tradicionales sobre la traducción, como la originalidad o la influencia

\footnotetext{
${ }^{8}$ Es la opinión de Steiner, por ejemplo, en relación a la traducción inglesa de La muerte de Virgilio (1945) de Hermann Broch por parte de Jean Starr Untermayer como un texto indispensable para comprender el texto original.

${ }^{9}$ Es este un carismático texto de Borges que, publicándose con variaciones y ediciones a partir del ensayo previo del autor publicado en La Prensa (Buenos Aires, 22 de abril de 1928, 2a sección, p. 5) titulado "El estilo y el tiempo", tendrá una segunda versión, fechada en 1930 y recogida en Discusión (Buenos Aires, Manuel Gleizer, 1932) [cfr., Pastormerlo 2006:124].

10 Aunque Borges desarrolla sus innovadoras ideas desde sus primeros escritos, incluyendo "Las dos maneras de traducir" (1926), sus impresiones y percepciones al respecto se completan en su ensayo de 1932 "Las versiones homéricas", donde aparece el aserto de que el concepto de texto definitivo no corresponde sino a la religión o al cansancio." [cfr., Waisman, en de Toro (ed.) 2010:88].
} 
literaria [cfr., Waisman, en Romero, 2015: 92] ${ }^{11}$. Borges termina alzándose, de este modo, como un defensor de que lo mejor de una traducción puede resumirse en sus infidelidades y no en los intentos por lograr una literalidad perfecta que sería, al cabo, imposible. Como escritor formado en la impureza, cuando Piglia dé forma a sus ensayos sobre el mundo del traductor no podrá sino tener muy en cuenta esta opinión borgiana. Se trata, no en vano, de una consideración crítica sobre la traducción -además de un posible modelo de producción cultural- que equipara subrepticiamente ensayo y traducción como distintas caras de un mismo género.

He aquí la razón por la que, más allá de la alarma que esta opinión de Borges pueda causar en la atención y desvelos del traductor, Piglia se pregunta qué quiere decir leer mal o si ello se relacionaría con la parte de una traducción que no está presente en el original traducido, interpelándose por el tipo de efectos que puede provocar una lectura que se desviase de lo que, en principio, pueden ser los sentidos dados del texto [cfr., Piglia, en Romero 2015:94]. El temperamento de autor impuro en Piglia le lleva, como vemos, a recortar posibles significaciones reveladoras en los caminos vedados, incorrectos o equivocados, desaconsejados o culpables. Contagiado de la impureza pigliana, Waisman se decide a escribir que "La mejor traducción quizás sea la que se hace en secreto y no se edita, como la del narrador al final de 'Tlön'" [Waisman, en Romero 2015:100], ya que la traducción siempre es equívoca, mala o desviada por no lograr ser nunca completamente fiel. Piglia ha ilustrado todos estos aspectos, entre otros, a través de la traducción china del Quijote ${ }^{12}$, de los mecanismos internos de "Pierre Menard, autor del Quijote" de Borges' ${ }^{13}$, de diferentes aspectos

\footnotetext{
${ }^{11}$ Otra versión del tema la encontramos en un temprano ensayo de Borges ("Las dos maneras de traducir", 1926) en el que este discurría sobre dos maneras de traducir: la traducción "romántica" o basada en el culto romántico del artista individual y del texto original y la traducción ajena a dichos cultos, que Borges denomina "clásica" [cfr., Pastormerlo 2007:64].

${ }^{12}$ A Piglia le divertía contar en sus conferencias cómo el escritor chino Lin Shu y su ayudante y amigo Chen Jialin son los primeros "traductores" al chino de El Quijote -bajo el título Mo Xia Zhuan (1922), lo que vendría a significar en español Crónica de un héroe enloquecido)- con la particularidad de que ninguno de los dos hablaba español. La traducción consistió en un trabajo traducido por Chen del inglés al chino en voz alta mientras su compañero Lin lo interpretaba de oídas para, a continuación, escribirlo en chino antiguo. Piglia decía que siempre quiso ver qué hubiera dado esa novela nuevamente traducida al español de un Don Quijote casi completamente imaginario y pasado por la mirada china. También le gustaba pensar, decía, en la idea de escribir un relato con ese dúo de traductores [cfr., Piglia 2017:269]. Es otro ejemplo de cómo los grandes libros pueden persistir más allá de sus traducciones. Recordemos que, aunque en la propia ficción del Quijote este aparece como una traducción del árabe -estaríamos, pues, ante una traducción que devendría elemento constitutivo de la ficción misma-, en la segunda parte de la obra, en el capítulo LXII, cuando don Quijote y Sancho llegan a Barcelona, don Quijote le dice a un traductor italiano que traducir de una lengua a otra, excepto si la traducción procede del griego o latín, es como mirar "los tapices flamencos por el revés".

13 "El gran problema teórico de Borges es el de la traducción. La traducción como relación entre culturas. De ahí «Pierre Menard, autor del Quijote», un texto sobre la novela y la traducción, sobre el doble contexto, pero sobre todo con una novela en el centro: el Quijote. Traducir, para Borges, es escribir una lectura. Escribir un texto que es el mismo y es otro. Mezclado con esto, el problema básico de la propiedad: ¿de quién es el texto traducido?, ¿qué relación con la propiedad tiene un traductor?, ese lugar incierto está en los textos de Borges." [Piglia 2016d:71].
} 
de la traducción en Saer, Walsh o Puig ${ }^{14}$, de la imposibilidad traductora de Finnegans Wake (1939) de Joyce ${ }^{15}$ o de la delirante traducción española de Ferdydurke (1939) sobre la que Piglia ha escrito brillantes e interconectados ensayos, como "La novela polaca" [cfr., Piglia 2015a:69-80] o "Borges y Gombrowicz", en el que leemos:

El polaco era una lengua que Gombrowicz usaba casi exclusivamente en la escritura, como si fuera un idiolecto, una lengua privada. De la relación de Gombrowicz con las dos lenguas, del cruce entre el polaco y el español, nos queda la traducción argentina de Ferdydurke, publicada en 1947. Conozco pocas experiencias literarias tan extravagantes y tan significativas. Parecen lenguas exiliadas: Gombrowicz escribía un primer borrador trasladando la novela a un español inesperado y casi onírico, que apenas conocía. Un escritor que escribe en una lengua que no conoce o que conoce apenas y con la que mantiene una relación externa y fascinada. O si ustedes prefieren: un gran novelista que explora una lengua desconocida, tratando de llevar del otro lado los ritmos de su prosa polaca. La tendencia de Gombrowicz, según cuentan, era a inventar una lengua nueva: no crear neologismos (aunque los hay en la novela, como el inolvidable de los culeítos) sino a forzar el sentido de las palabras. Trasladarlas de un contexto a otro, y obligarlas a aceptar significados nuevos. Sobre este material primario comenzaba el trabajo de un equipo heterogéneo y delirante "bajo la presidencia de Virgilio Piñera distinguido representante de las letras de la lejana Cuba", según recuerda Gombrowicz en el prólogo a la primera edición. [...] Este equipo no conocía el polaco y los debates se trasladaban a menudo al francés, lengua a la que Gombrowicz y Piñera se cruzaban cuando el español ya no admitía nuevas torsiones. Cubano, francés, polaco, "argentino": lo que se llama una mezcla verbal, una materia viva. [...] El Ferdydurke "argentino" de Gombrowicz es uno de los textos más singulares de nuestra literatura. [...] [en el que] el español está forzado casi hasta la ruptura, crispado y artificial, parece una lengua futura [Piglia 1987:13-15].

Nada tiene de extraño, pues, que el espacio práctico y ensayístico de la traducción se relacione con el aspecto, fundamental en Piglia, de vivir en otra lengua ${ }^{16}$, tanto por lo que para todo autor la traducción denota en el recorrido conceptual de la interpelación literaria -especialmente

14 "Cuando Puig gana un público internacional, empieza a dejar de escribir con ciertas particularidades lingüísticas ligadas a algunas zonas de la provincia de Buenos Aires y se vuelca, cada vez más, a una lengua de traducción, a una lengua que se puede leer en cualquier país de América Latina sin notar la diferenciación. [...] Esta operación estilística se ve también, por ejemplo, en las grandes traducciones de Enrique Pezzoni, Wilcock, Pepe Bianco, Aurora Bernárdez, que consiguieron construir un estilo a partir de una marca literaria sin marcas regionales, neutra, casi inexistente, y que puede ser leída en Madrid, en Buenos Aires o en Caracas sin notar particularidades." [Piglia 2016d:71-72].

15 “La relación entre novela y traducción está en El Quijote (porque leemos en realidad una traducción del árabe), en el origen del género. Y Joyce es el fin de la novela porque el Finnegans Wake no se puede traducir [...] Un texto escrito para que no pueda ser traducido pero, a la vez, con la ilusión de que pueda ser leído en todas las lenguas, porque tiene todas las lenguas dentro suyo." [Piglia 2016d:71]. Aunque Finnegans Wake ha sido recientemente traducido por primera vez al español (Marcelo Zabaloy, El Cuenco de Plata, 2016), no le faltaba razón a Piglia cuando mantenía que se trataba de un texto intraducible porque hasta este trabajo, publicado en Argentina, la obra más inaprensible de Joyce solo había sido traducida a lengua española en contadas ocasiones y siempre parcialmente -fue el caso, entre otros, de Francisco García Tortosa (Cátedra, 1992)-. Añádase, por último, que igualmente aparentó ser durante mucho tiempo intraducible Zettels Traum (1970) de Arno Schmidt -obra, no por azar, inspirada en el Finnegans joyceano- hasta la reciente y sorpresiva traducción al inglés de John E. Wood (Bottom's Dream, Dalkey Archive Press, 2016).

${ }^{16}$ Lo cual remite directamente a "la experiencia de la novela moderna" [Piglia 2000:74]. 
partiendo de la experiencia de pertenecer a una cultura secundaria- como por la reflexión que subyace a los modos o posibilidades de discutir la tradición propia ${ }^{17}$. Piglia ha reflexionado sobre las experiencias modernas de escribir y vivir en una lengua extranjera en los casos, entre otros, de Beckett, Conrad, Gombrowicz, Jerzy Kosinski, Bashevis Singer o Nabokov hasta el punto de considerar la traducción como un capítulo fundamental de la historia del género novelístico ${ }^{18}$, ya que no solo toda traducción es siempre una "retraducción" - de historia de la traducción- al decir de Meschonnic ${ }^{19}$ sino que, desde la estandarización de la traducción, la novela como género se ha podido mover históricamente entre distintas fronteras, lenguas y lectores como viaje e investigación, los dos motores más eficaces de la narrativa moderna, tal y como opina Piglia [2016c:25], añadiendo, de hecho, que la historia de las traducciones es una historia del estilo y no por azar, a menudo, las traducciones terminan por fijar el estado del estilo con más claridad que los propios escritores. La novela -a diferencia de la poesía-, continúa Piglia, está hecha "para soportar la traducción"; es decir, si el poeta es "aquel que es fiel a su lengua", el novelista quisiera "ser leído en cualquier lengua" [cfr., Piglia 2016d:69-71].

Entre el resto de profesiones culturales -dentro del organigrama cultural de nuestro tiempo antes citado- en las que Piglia intervino de una u otra forma, podríamos referirnos muy brevemente a dos más: las del editor y la del compilador, las cuales ejercerían igualmente de agentes activos y selectivos de la circulación literaria que va a retroalimentar los circuitos de exposición e influencia críticas dentro de un mercado específico de producción literaria, lo que nos conduce, de nuevo, a Piglia como factótum impuro de la modernidad literaria desde, al menos, dos sentidos: en primer lugar, porque Piglia tiende a ocuparse de la periferia de la creación literaria, partiendo no tanto de los géneros literarios en sí mismos ni canónicamente entendidos sino radicándose sobre los componentes entrecruzados y consustanciales de dicha periferia creativa: fundamentalmente desde la posición del lector, el traductor y el crítico; en segundo lugar, porque Piglia presta atención, en muchos casos, a los autores y las actitudes que considera pervertidos o infectados de una irreverencia vital en relación a los valores culturales de la tradición burguesa, organizados en relación a la norma, el

\footnotetext{
${ }^{17}$ Esta cuestión puede rastrearse fundamental pero no exclusivamente en los ensayos piglianos escogidos para la ocasión por González Sawczuk [2008:90-98] “¿Existe la novela argentina? (1986), "Ficción y política en la literatura argentina" (1987), "Roberto Arlt, la ficción del dinero" (1974) y "La marca de Arlt" (1999).

18 "Siempre me ha llamado la atención que el filólogo alemán E. M. Curtius, en su libro Literatura europea y Edad Media latina, señalara que romanzar -la palabra que define la traducción del latín a las lenguas vulgares- es el origen de romance, una versión de novela en inglés, y de roman, el nombre en francés del género. La palabra romance que designa el género deriva de la técnica de traducir (romanzar, enromancier) y alude así al origen histórico del género, es decir, a la tensión entre las lenguas vernáculas y el latín escrito." [Piglia 2016d:69].

19 “Traduire, même ce qui n’a encore jamais été traduit, c’est toujours déjà retraduire. Parce que traduire est précédé par I'histoire du traduire" [Meschonnic 1999:436].
} 
poder y la corrección. Contra ello reacciona Piglia, apoyado en el valor de la opacidad, lo marginal o descentrado, en lo inmaduro, lo heterodoxo y lo que va a contracorriente, en la oscuridad, el complot y en cuanto linda con lo delincuencial, en la excentricidad y la rareza, en la utopía y la extranjería..., elementos todos ellos, en fin, paradigmáticos de los escritores de las afueras literarias en un sentido fuerte.

Por último, también la "impureza" de Piglia alcanza o afecta a su modo y momento de leer, creyendo Piglia que sus lecturas son más productivas cuanto mayores desvíos toman desde sí mismas, cuando lee, por ejemplo, a destiempo y de forma descontextualizada ${ }^{20}$. Una breve lista de los autores restañados o revalorizados por la crítica pigliana, paradigmáticos de ciertas alegorías de la impureza, nos conduciría a Gombrowicz (desde su extrema periferia cultural y lingüístico-nacional, desde la polisexualidad de arrabal y las carencias socioeconómicas), Pavese (desde sus complejos sexuales, la latente impotencia que termina por proyectar una misoginia salvaje en su diario y su torturada necesidad suicida), Kafka (desde su megavisión histórica de la interpretación de la ley, su judaísmo culposo y su rechazo del matrimonio acompañado tanto de la angustiosa devaluación de sus instintos psico-románticos como de la neurastenia creativa en torno a la escritura literaria), Beckett (desde la renuncia a su lengua materna y su ensimismamiento en las imposibilidades del lenguaje), Arlt (imbuido de empresas comerciales fracasadas, conocedor de una conflictiva vida sentimental y proclive a una extrema familiaridad con los suburbios del arte), Macedonio (valiéndose de ideas y propósitos quijotescos para sobrevivir a la vez que empleando su vida en una novela eternizada en nombre de un amor imposible) o Borges, a pesar de su estatus burgués (desde la abisal soledad en la que le sume su ceguera, que parte su vida en dos mitades ya jamás alícuotas). Pero también a Joyce (a quien, tras la ruina familiar en su adolescencia, le esperaba una vida errabunda y accidentada -hasta el punto de llevar a Lacan a preguntarse por la locura del autor irlandés- pero al que, sobre todo, le aguardaba una obra que aspiraba a la intraducción) u Onetti (que da la espalda a los fastos literarios y al reconocimiento de la crítica en su modesto piso de la madrileña Avenida América para varar su vida entre las fidelidades literarias con las que pasa sus últimos años, voluntariamente postrado en una cama con respaldo móvil): desde estas impurezas y periferias literarias se constituyen no pocos de los espacios centrales del ensayismo "impuro" y sobre los "impuros" de Piglia.

\footnotetext{
${ }^{20}$ El 13 de mayo de 1971 escribe Renzi en su diario: "Mis lecturas en los últimos meses (sobre todo Joyce y Brecht) me confirman que Ilevo cinco años de 'atraso' (por lo menos) respecto del resto de mi generación. Leo siempre a destiempo y esa lectura es muy productiva, trabajo siempre los libros fuera de contexto, en otras relaciones ligadas a mi propio ritmo y no al aire de la época. Por ejemplo, en Brecht me interesan los ensayos y no el teatro, y en Joyce busco sus formas clásicas y no tengo nada que ver con el fluir de la conciencia que hace estragos en mis contemporáneos. Ser de vanguardia es estar a destiempo, en un presente que no es de todos." [Piglia 2016e:248].
} 


\section{Los ensayos de Piglia: escritura y lectura como formas de vida}

Pero, sin duda, si desde algún lugar Piglia ejerce el papel de factótum cultural de la modernidad literaria de su tiempo por encima del resto de posibilidades, ese lugar es el que remite al feraz territorio de sus ensayos. Por esta razón, llegados a este punto, cabría comenzar posiblemente no tanto reivindicando el ensayo de Piglia -que aunque ha sido menos tratado y ponderado que su narrativa tampoco ha pasado exactamente inadvertido para público y crítica ${ }^{21}$ - como, simplemente, equiparándolo a su obra narrativa. El ensayismo de Piglia -en especial reforzado hoy por la que me parece que puede quedar como una de las piedras angulares de su obra con ese diarismo sui generis filtrado por la transpiración y bilocación renzianas del autor- ofrece una serie de claves en su etapa madura que, hechas las convenientes excepciones, no siempre alcanza a igualar su narrativa. De hecho, la narrativa del autor que nos interesa en mayor medida suele ser la que no renuncia ni se desdice de posibles tratamientos ensayísticos. Al respecto, y de modo sucinto, podríamos pensar, por ejemplo, en ese admirable tour de force que es Respiración artificial (1980), probablemente una de las diez novelas imprescindibles del siglo XX argentino por la construcción técnica y fluidez narrativa de la obra pero también, sin duda, por ese cierto vigor hipnotizante que suele darse en el punto de vista y la temática adoptados por Piglia a la hora de fijar su trabajo, bajo los cuales suele quedar atrapado el lector mientras se mantiene en pie la aventura ensayística que aquella contiene. Igualmente, Piglia escribió notables relatos; entre otros, los que se contarían entre aquellas historias que, marcadas por una acentuada ascendencia mítico-literaria, entreveran ficción y autobiografía con distintos y pendulares movimientos metacríticos: es el caso de los relatos, explícitos desde sus títulos en relación a la figura literaria a la que homenajean, "Homenaje a Roberto Arlt" [1975:97-172] y del extraordinario "La isla de Finnegan" [2016a:225-239]22, así como ocurre lo propio con "Un pez en el hielo" [2016a:39-54] como muestra de admiración por Pavese. Por último, son también destacables ciertos relatos de Piglia que, sin incursionar reflexiva ni necesariamente en el mundo del arte o la creación literaria, recrean, por ejemplo, inspiradamente aspectos populares y sociológicos del Buenos Aires pigliano -lo cual encontramos, por ejemplo, en ese excelente canto al agridulce

\footnotetext{
${ }^{21}$ En los veinte últimos años se ha sucedido la publicación de un considerable número de estudios monográficos, compilaciones críticas u otros dedicados a la obra de Piglia, dándose en buena parte de los mismos un espacio total o parcial dedicado al ensayismo del autor. Entre otros, podríamos destacar los siguientes: Bratosevich [1997], De María [1999], Corbatta [1999], Fornet [2000, 2005, 2007], Quintana [2001], Pereira [2001], Rodríguez Pérsico [2004], Giordano [2005], Mesa Gancedo [2006], Corral [2007], Carrión [2008], González Sawczuk [2008], González Álvarez [2009], Orecchia Havas [2010, 2012], Romero [2015].

${ }^{22}$ Relato procedente de La ciudad ausente (1992) y en el que las peculiaridades de la isla con la que se titula el texto hacen que a veces un hombre y una mujer sean amantes apasionados en una lengua y hostiles y apenas conocidos en otra [cfr., Piglia 2016a:228].
} 
mundo del boxeo porteño que es "El laucha Benítez cantaba boleros"23, cuyo título homenajea "Ella cantaba boleros", una parte de Tres tristes tigres (1967) que luego se independiza y se publica como obra individual en 1996-, derivan hacia lecturas y tratamientos literarios de la lucha revolucionaria y política argentinas -tal y como ocurre con "Mata-Hari 55" [1967:55-68]-, aparecen como cotidianos tratados de introspección sentimental -lo que podría ejemplarizarse con el tributo a Fitzgerald titulado "Tierna es la noche" [1967:103-113]- o que, por último, se concentran en una presunta anécdota personal desde la que se materializa un fulgor narrativo bajo forma de trasunto literario -lo cual encontramos, v. gr., en "Hotel Almagro" [2015a:7-12]-. Es decir, todas estas cotas literarias, entre otras que no citamos aquí, han contribuido a considerar legítimamente la narrativa de Piglia como una de las más sugestivas y originales del panorama literario hispanoamericano de las cinco últimas décadas: la condición de factótum cultural del tiempo que le tocó vivir, pues, se nutre también de sus logros en la creación narrativa.

Dicho lo cual, sin embargo, me parece que el ensayo de Piglia ha ido mostrando desde la primera recopilación de sus textos ensayísticos y entrevistas -concretamente a través de Crítica y ficción (1986)- cierta y desenvuelta supremacía en la madurez de un escritor ocupado en radiografiar, como intérprete público de primer orden y bajo unos modos de escritura personalísimos, a los grandes autores de la modernidad hispana y europea, desplegando justamente ahí una sobresaliente soberanía lectora. Dicho de otro modo, difícilmente nadie podría asegurar, entre muchos otros ejemplos que podrían aducirse, que ensayos tan deslumbrantes como "El escritor como lector" [2016a:83-98] o "Ernesto Guevara, el último lector" [2016a:263-295] puedan tener nada que envidiar a ninguna pieza narrativa de Piglia. Ello no solo legitima orgánicamente la homologación entre los discursos narrativo y ensayístico en Piglia sino que en no pocos casos el ensayo del autor queda contagiado, una vez entra en el circuito oficial de la crítica, de cierta elocuente sensación de parecer imprescindible.

Lo que hace de Piglia, de hecho, un crítico diferenciado como factótum cultural de su tiempo es el hecho de lanzar en las distintas manifestaciones de sus ensayos una serie de apreciaciones lectoras y teorías personales que, estando lejos de ser tentativas, terminan implantando en el sustrato colectivo de la comunidad literaria el modo pigliano de leer a los demás. Piglia glosa y comenta, interpreta y amplía, pero va más allá de ello: se trata de una glosa que más que recorrer o analizar lúcidamente tramos y escenas de la literatura -que, desde luego, también-, lo que hace es proponer estatutos

\footnotetext{
${ }^{23}$ En muchos casos los diarios de Renzi nos proporcionan el proceso de creación y posteriores modificaciones de sus obras narrativas en curso. Por ejemplo, para "El laucha Benítez cantaba boleros" -recogido también como "El Laucha Benítez" [2016a:27-38]- tenemos noticias del mismo durante los meses de septiembre y octubre de 1967 o mayo y septiembre de 1978 [cfr., Piglia 2015b:326, 329; 2016e:30, 63].
} 
de facto, sugerir lecturas que vienen para quedarse; son presunciones e hipótesis que desplazan la capacidad y la habilidad de sustentar una convicción integral sobre un autor, marco conceptual o hecho literario concretos para terminar estableciendo continuidades teoréticas esclarecedoras, en muchos casos, directamente seductoras -por vía del carácter, del charme, de su estilo literario- para los lectores que merodean las redes de tránsito valorativo entre Piglia y sus objetos de ensayo.

Además de la ya citada Crítica y ficción, las otras obras ensayísticas carismáticas de Piglia serían, fundamentalmente ${ }^{24}$, Formas breves (1999), El último lector (2005), La forma inicial. Conversaciones en Princeton (2015) -obra publicada previamente como Ricardo Piglia. Conversación en Princeton (1999) - y Las tres vanguardias. Saer, Puig, Walsh (2016). A estos se les uniría parcialmente, por su abundante carga de apuntes y fragmentos ensayísticos, el ya mencionado dietario del autor. Vamos a ver cómo, tomando cuatro de los títulos de estos ensayos, podría cubrirse el arco entero que va desde la escritura a la lectura -y no al revés, como suele ocurrir en los escritores ${ }^{25}-\mathrm{o}$, en realidad, desde el principio del lenguaje articulado en la especie humana y su evolución comunicativa hasta el cierre colectivo de la experiencia lectora.

Podríamos así empezar abordando el que fue uno de los últimos libros publicados por Piglia -aquel que recogió una serie de conversaciones mantenidas por él entre abril de 1998 y diciembre de 2008 con diversos colegas y alumnos de la Universidad de Princeton-, el titulado La forma inicial (2015). Dotadas de un notorio tono ensayístico, dichas conversaciones culturales discurren entre las posibilidades de renovación de los modos de narrar en relación a la forma nouvelle y las experiencias de Piglia en torno a la escritura y la enseñanza de la literatura, enmarcadas dichas experiencias, especialmente, en el contexto de la academia universitaria estadounidense. Sin embargo, en relación a la obra La forma inicial nos ceñiremos aquí, fundamentalmente por razones de espacio, en el ensayo que abre y titula el volumen.

Decía Mandelstam que el poeta es un maestro del eco porque ningún ser humano puede ir al origen del sonido inteligible, el que fue compartido desde un mismo código e incluyó a un emisor

\footnotetext{
${ }^{24}$ Otras valiosas obras ensayísticas del autor serían Diccionario de la novela de Macedonio Fernández (Fondo de Cultura Económica, 2000), Teoría del complot (Mate, 2007), su libro de conversaciones con Saer titulado en su última edición Por un relato futuro (Anagrama, 2015) o Escritores norteamericanos (Tenemos las máquinas, 2016) -reedición de los inspirados ensayos de Piglia a modo de notas introductorias de la antología que este preparó para Jorge Álvarez en 1967 bajo el título Crónicas norteamericanas-. Otras antologías de Piglia que incluyeron igualmente selección, prólogo y notas a su cargo fueron, por ejemplo, Yo (Tiempo contemporáneo, 1968) o Crónicas de Latinoamérica (Jorge Álvarez, 1968). Para un seguimiento de las publicaciones de Piglia, así como de sus colaboraciones dispersas en revistas u otros, véase, v. gr., Mesa Gancedo (coord.) (2006).

${ }^{25}$ Se cumple así aquello que dijera Rancière acerca de que "Lo real debe ser ficcionado para ser pensado" [2009:48]. He aquí el motivo por el cual Piglia se plantea la manera bajo la que la ficción construye la realidad y no al contrario, fijándose, entre otros, en Alonso Quijano -esto es, prestando atención al modo bajo el que sus lecturas le organizan una realidad distinta, debatida y construida desde el juego de lo posible y lo real-o en Borges, cuya lectura de tan intensos efectos sociales logra persuadirnos de que la realidad está o pudiera estar tejida con elementos imaginarios; de hecho, que nos creamos siempre uno y el mismo es -solía decir Piglia- un relato imaginario.
} 
y a un receptor, jugando por ello hoy el poeta, desde la intuición simbólica y la necesidad lírica, interminablemente, con lo que no sería sino el eco de aquel primer sonido imaginario. Es lo que, a su modo, hace Piglia interrogándose y yendo a la búsqueda de "la forma inicial", la forma con la que todo empezó, incluida, desde luego, su historia personal como escritor ${ }^{26}$. Para ello, Piglia se pregunta por el problema de los usos del lenguaje como parte de la gran tradición de la reflexión sobre el sentido y se fija específicamente en la noción de narración como uno de los modos más estables del uso del lenguaje, siendo incluso, quizá, la narración, el origen mismo del lenguaje o la forma primera de estímulo individual y social que tiró del lenguaje. El escritor argentino imagina entonces cómo fue el primer relato, "la prehistoria de los grandes modos de narrar" [2016c:25], barruntando que quizá el primer narrador se alejó de una cueva persiguiendo una presa hasta que desembocó en un valle, vio algo extraordinario y volvió para tratar de contar esa experiencia a los suyos. El protagonista, en todo caso, fue un viajero, aquel que, al explicar su viaje y compartirlo con el resto de la tribu, habría fundado "una de las estructuras centrales de la narración" [ibid., 26]. En otras palabras, se trata siempre de ir o de volver a algún lugar para contar algo, para poder ver y transmitir una diferencia; narrando nuestro acceso a algo ajeno o cambiante podemos sentirnos, incluso ser, diferentes: "No hay viaje sin narración, en un sentido podríamos decir que se viaja para narrar" [idem]. Otra posibilidad, asegura a continuación Piglia, es fantasear con la idea de que el primer narrador "ha sido el adivino de la tribu, el que narra una historia posible a partir de rastros y vestigios oscuros. Hay unas huellas, unos indicios que no se terminan de comprender, [y resulta] necesario descifrarlos y descifrarlos es construir un relato" [idem]. Piglia presenta, pues, el viaje y la investigación -ya lo comentamos antes- como los dos modos de narración básica, anteriores a los géneros y constructores de sus propios héroes.

El primer héroe de "la forma inicial", el que protagoniza el modo de narrar del viajero, es Ulises, el que está lejos, el que añora el retorno y vive en el nomadismo; es el sujeto que está siempre en situación precaria, el que vive con la nostalgia de algo que ha perdido, arguye Piglia. El otro héroe de la forma inicial, el perteneciente al modo de narrar propio del investigador, sería Edipo, el descifrador de enigmas, "el que investiga un crimen y al final termina por comprender que el criminal es él mismo" [ibid., 29]. Ulises y Edipo, pues, quedan, añadimos, como los héroes de las dos posibles formas iniciales de narrar: son los dos grandes modelos del relato y de la construcción de

\footnotetext{
${ }^{26}$ En el texto que abre el segundo volumen de Los diarios de Emilio Renzi podemos leer: "[...] en esa serie, vivir, escribir, ser leído [...] descubrí una morfología, la forma inicial, como me gustaría llamarla, de mi vida registrada, día tras días, en mi diario personal" [2016e:15].
} 
la subjetividad. Tras dejar esto sentado, Piglia termina su ensayo invocando a Leo Strauss en alusión a las dos grandes tradiciones culturales identificadas con las ciudades de Atenas y Jerusalén. Esto es, la tradición filosófica del concepto procedente de la tradición griega versus la tradición narrativa de la Biblia aparejada a la experiencia de la revelación: “Cristo con las parábolas, las fábulas y los relatos da a conocer la verdad de una manera distinta al modo en que la verdad se da a conocer a través del concepto" [ibid.,30].

Tras haber considerado la "forma inicial", la que daría carta de naturaleza a la narración desde sus orígenes, podríamos pensar en las Formas breves (2000), esto es, las formas en las que comienza a forjarse un posible oficio escritor, las formas borgianas, las escuetas, las que responden a una fórmula de ensayo breve y conciso en busca de la justeza y la precisión. Son formas breves que, para esta obra, además, están ocasionalmente tomadas por Piglia de ciertas páginas autobiográficas y ensayísticas de los diarios de Renzi, todavía entonces no publicados conjuntamente. En efecto, desde sus primeras publicaciones en una editorial en 1967 -Jaulario en Cuba y la ampliación y modificación de esta, La invasión, en Buenos Aires durante el mismo año- y hasta 1980, con la aparición de Respiración artificial, las formas breves fueron la formación técnica y sentimental de Piglia. Son trece años en los que Piglia escribe fundamentalmente -en los que, sobre todo, publicaúnicamente cuento y ensayo, "formas breves". Durante esta primera etapa literaria le preocupa a Piglia decir lo suyo a través de las formas breves pero hacerlo de forma diferente, esto es, buscando al mismo tiempo alejarse de los dos modelos que capitalizan prácticamente por entonces las letras argentinas: Borges, al que Piglia admira, quizá, por encima de todo, y del que lee regularmente las formas breves de los cuentos, poemas y ensayos que nunca dejó de escribir, y Cortázar, con el que Piglia mantiene mayores distancias en el ámbito de sus afecciones literarias pero del que valora extraordinariamente muchos de sus cuentos ${ }^{27}$.

Paralelamente a su labor como cuentista durante esta etapa de formación, la otra manera pigliana de decir sus formas breves, mediante el ensayo, se centra en la elección de los temas y autores y en la originalidad del tono empleado. Entre los primeros ensayos de Piglia -textos que no se recogieron ni en la primera selección de ensayos Crítica y ficción (1986) ni en los recopilados para Formas breves (2000)- que podrían empezar a dar cuenta de parte de lo antedicho sobre el ensayismo del autor podríamos citar "Los diarios de Pavese" [2015b:142-146], escrito en 1963,

\footnotetext{
27 No en vano, tanto Borges como Cortázar determinaron la predilección -podríamos decir también la "huida"- de Piglia hacia la literatura norteamericana. Así lo confirma Piglia en un breve párrafo escrito el lunes 10 de julio de 2016 para el prólogo de la cuidada reedición de sus notas ensayísticas para la anteriormente citada antología de autores norteamericanos: "Mi entusiasmo por la narrativa norteamericana, comprendo ahora, fue una reacción frente a la influencia de Borges y Cortázar, que hacían estragos entre los escritores de mi generación. La invasión [...] tiene, creo, la marca de esas lecturas." [2016b:7].
} 
cuando Piglia está todavía en la universidad, o las brillantes notas biográfico-críticas sobre los escritores norteamericanos escritas cuatro años después a las que ya nos hemos referido antes y en las que el joven Piglia combina, en efecto, agudos comentarios críticos con un ritmo y un estilo periodístico-literario abultado de hallazgos expresivos y sugestivas anécdotas sobre los recorridos vitales de los escritores tratados ${ }^{28}$.

Cuando Piglia recopila a finales del siglo XX, pues, un conjunto de formas breves, y estas aparecen tituladas precisamente como Formas breves (2000), el autor tiene tras de sí casi cuarenta años de experiencia en aquellas. Aunque se trata de autores que estaban ampliamente citados y analizados en los ensayos de Piglia desde décadas atrás, en estas Formas breves las figuras de Macedonio, Borges y Gombrowicz ostentan una indudable posición de mandamases. El libro se abre, por ejemplo, con un texto al que ya me referí antes, desarrollado bajo la entera sombra de Gombrowicz y presente también en el primer volumen de los diarios de Renzi, "Hotel Almagro" [2015a:7-12], no siendo este sino el lugar de la zona bonaerense en Rivadavia y Castro Barros en la que Piglia alquilara una pequeña habitación y escribiera sus primeros relatos al mudarse a la capital argentina mientras no dejaba de dar clases varios días por semana en la Facultad de Humanidades de La Plata ${ }^{29}$. Más adelante en la obra, por cierto, la forma breve "La mujer grabada" [ibid.,29-33] funcionará como secuela o continuación de "Hotel Almagro". Otros destacados ensayos del libro son "Un cadáver sobre la ciudad" [ibid.,35-39] -breve texto en el que Piglia dice haber tenido la oportunidad de ver una serie de fotografías del velorio de Arlt, siendo una de dichas imágenes especialmente inolvidable ${ }^{30}-$, "La novela polaca" $\left[\right.$ ibid.,69-80] ${ }^{31}$ o su famoso ensayo "Tesis sobre el cuento" [ibid.,103-111], el cual Piglia desarrolló a partir de una anécdota registrada en los cuadernos

\footnotetext{
${ }^{28}$ Los autores no fueron totalmente escogidos por Piglia, ya que él hubiese querido incluir, por ejemplo, a algunas de las grandes damas del sur estadounidense durante el siglo XX como Katherine Anne Porter, Carson McCullers, Flannery O'Connor o Eudora Welty. La lista final quedó configurada con los nombres de Ring Lardner, Sherwood Anderson, Thomas Wolfe, William Faulkner, Scott Fitzgerald, Ernest Hemingway, Erskine Caldwell, Nelson Algren, Truman Capote, James Purdy, John Updike y James Baldwin.

29 "Hotel Almagro", por cierto, es leído por el propio Piglia en voz en off en los comienzos narrativos del documental Macedonio Fernández (1995) de Andrés Di Tella, en el cual Piglia aparece también como parcial protagonista, mezclando la narración biográfica de Macedonio con episodios autobiográficos de los primeros tiempos de la vida de Piglia en Buenos Aires en pos de las huellas de Macedonio. Piglia, por cierto, aparecería también en el documental de 1997 de Andrés Di Tella sobre la última dictadura argentina titulado Prohibido [cfr., Carrión 2008:12] y veinte años más tarde, tras aquel primer documental sobre Macedonio, de nuevo Andrés Di Tella -perteneciente a una familia a través de la cual puede seguirse la reciente historia política y cultural argentina (véase, Nicolás Cassese, Los Di Tella, una familia, un país, 2008)- se haría igualmente cargo del documental 327 Cuadernos (2015) sobre los diarios de Piglia. Para cerrar el círculo literario que protagoniza en Formas breves la triada Macedonio-Borges-Gombrowicz, cabría decir que Andrés Di Tella también colaboró en el documental de Alberto Fischerman Gombrowicz, o la seducción (Representado por sus discípulos) (1986).

30 "La más impresionante era una toma del féretro colgado en el aire con sogas y suspendido sobre la ciudad. Habían armado el ataúd en su pieza, pero tuvieron que sacarlo por la ventana con aparejos y poleas porque Arlt era demasiado grande para pasar por el pasillo [...] Su cadáver sigue sobre la ciudad. Las poleas y las cuerdas que lo sostienen forman parte de las máquinas y de las extrañas invenciones que mueven su ficción hacia el porvenir." [Piglia 2015a:39].

${ }^{31}$ Texto publicado, entre otros lugares, en Crítica y ficción con el título “¿Existe la novela argentina?” [1989:49-57].
} 
de notas de Chéjov en torno a la idea de que un relato siempre cuenta dos historias y cada una se narra de modo distinto, construyéndose en secreto la historia segunda mientras en primer plano se narra la historia primera ${ }^{32}$.

Otras formas breves con las que continuaríamos camino por el ensayismo de Piglia incluiría los ensayos que bajo formato de reelaboradas y persuasivas entrevistas aparecerán recopilados en Crítica y ficción (1986), siendo esta, probablemente, la obra ensayística más completa o trasversal para entrar por primera vez en el mundo de Piglia. Su título no puede ser más significativo, ratificando, de hecho, los dos elementos léxicos que más frecuentemente se han visto imbricados en la literatura de Piglia. Aparecen en estos ensayos, sin duda, no pocas de las claves de interpretación que mayor fortuna han tenido en el ideario crítico de Piglia. En el texto "La lectura de la ficción" leemos, por ejemplo, que la crítica es una de las formas modernas o posfreudianas de la autobiografía ya que "toda crítica se escribe desde un lugar preciso y desde una posición concreta" [2000:13], concibiendo Piglia la crítica también, por otra parte, como una variante del género policial en la que el crítico es el investigador y el escritor es el criminal. De Arlt escribe Piglia, por ejemplo, que es alguien que no es un clásico, ya que ello es aplicable a quienes están muertos o que, en todo caso, Arlt sería un clásico sin legitimidad, un desplazado que vive ajetreado entre su estilo de lunfardo con acento extranjero y su condición de escritor profético. Aparecen en esta obra también, entre otros muchos temas, la teoría del complot aplicada a los mecanismos de la creación literaria, la detallada interpretación de la importancia capital del Facundo (1845) de Sarmiento o, entre otros, finísimas aproximaciones críticas a Cortázar, Gombrowicz, al laboratorio de la escritura, al género policial, a la revista Sur, a Borges, a Faulkner, a la ficción y a la política en el seno de la literatura argentina, etc.

Por último, el cuarto y último título que cerraría el círculo de nuestra serie hace referencia a la obra El último lector (2005) -probablemente el más brillante de los ensayos de Piglia entendidos estos como publicación unitaria u orgánica-, concluyendo con ello ese mapa vital pigliano que hemos abierto con "la forma inicial" y que ha extendido sus dominios desde la escritura a la lectura con los movimientos ensayísticos de "las formas breves" y "la crítica y la ficción". El último lector, inaugurado con un prólogo que es a su vez una versión del excelente relato "La moneda griega" [cfr., Piglia 2015b:273-280]³3, que Piglia situó en el cierre del año 1966 dentro del primer volumen de los diarios de Renzi, es el ensayo que, como teoría de la lectura, redime al "lector adicto,

\footnotetext{
32 Se trata de una tesis en la que Piglia empezó a pensar desde muy joven. El 11 de septiembre de 1967 escribe Renzi en su diario: "Todos los cuentos que dejan una huella se construyen a partir de algo oculto." [2015b: 324].

33 Dracma que, como objeto de buena suerte, le entregara a Lucía -la compañera sentimental de Renzi en "Diario de un cuento" (1961)- un mendigo con aires de Raskólnikov tras haberle dado ella, previamente, a este último, un fajo de billetes [Piglia 2015b:117-118].
} 
el que no puede dejar de leer, y el lector insomne, el que está siempre despierto [...] [a través de] representaciones extremas de lo que significa leer un texto, personificaciones narrativas de la compleja presencia del lector en la literatura." [2005:20-21]. Los últimos lectores son para Piglia los "lectores puros", para los que la lectura, más que una práctica, es una "forma de vida". Al cabo, El último lector es la obra que, recorriendo muy diversas tipologías de lectores desde la extracción de una sucesión de escenas públicas o privadas de la historia de la literatura, logra materializar una impecable relación de conexiones, intuiciones y descargos personales desde la propia experiencia de la lectura como ligazón extrema con su sujeto o lector último. Borges, situado en una de las galerías altas de la Biblioteca Nacional de la calle México, con su ceguera a cuestas, es el primero de los últimos lectores. Anna Karenina, leyendo en el tren con una linterna, es la última lectora del libro. Entre ambos desfilan todos los héroes con un libro en la mano de Piglia, todos los que le han hecho ser quien es, incluido Ernesto Guevara, al que Piglia dedica la soberbia aproximación literaria a la que ya nos referimos antes. La fluidez de la prosa de ideas, el talento expositivo y la multiplicidad de anécdotas, percepciones y observaciones sobre los últimos lectores hacen de este ensayo, desde luego, un texto paradigmático del mejor nervio ensayista de Piglia.

\section{Los diarios de Emilio Renzi: un destino cumplido}

Lo dijimos antes. Es posible que la clave de bóveda de un escritor ya de por sí -antes de la publicación de Los diarios de Emilio Renzi- tan plural y dotado como Piglia pueda o vaya a ser su diario personal, una obra que abre y cierra paradigmáticamente una probada vida de escritor. Recordemos que Piglia "decidió" antes que nada, por encima de todo, "ser escritor". Esta fue una decisión tomada en los años 1958 y 1959, cuando el adolescente que entonces era Piglia acababa prácticamente de empezar su diario personal a finales de 1957. Estos diarios no solo le confirman como un factótum y mandarín cultural de la Argentina de su tiempo, con su nombre apareciendo en los ambientes literarios, desde muy pronto, como una inconfundible señal de autor vanguardista y distintivo, involucrado progresiva y absolutamente en toda la vida pública, social y cultural de Buenos Aires, sino que le encaraman visiblemente a una posición de privilegio dentro del espacio de la modernidad literaria hispanoamericana. Veamos lo que escribía sobre aquella decisión de ser escritor Emilio Renzi en dos notas de su diario a principios de 1965: 
[...] tengo que comprender que sólo mi literatura interesa y que aquello que se le opone (en mi cabeza o en mi imaginación) debe ser dejado de lado y abandonado, como he hecho siempre desde el principio. Ésa es mi única lección moral. Lo demás pertenece a un mundo que no es el mío. Soy alguien que se ha jugado la vida a una sola baraja. [...] Como siempre, me espera algo parecido a un mandato (de nadie), un mandato que yo mismo he construido para mí (escribir y ser un escritor). [2015b:170,173]

Efectivamente, Renzi se jugó la vida a la baraja única de la escritura, la verdadera o la que no se limita a la redacción ${ }^{34}$. Y en esa apuesta, en el hecho de que se cumpliera tal destino, ha tenido, desde luego, mucho que ver el diario de la vida renziana. No por azar nos han llegado Los diarios de Emilio Renzi (2015-2017) como un conmovedor texto de despedida que mezcla verdaderos ecos litúrgicos sobre la lectura y la escritura desde la infancia y adolescencia del autor con una sostenida determinación antisentimenta ${ }^{35}$. A la vez refutación y apoteosis del olvido, con su carácter casi mecanicista por registrar hasta los más mínimos detalles, su embriagadora celebración de la ficción y su obsesivo desvelo por la técnica literaria, los tres volúmenes de los diarios de Renzi nos han permitido acceder a un artefacto de modernidad literaria que resulta por momentos hechizante, siendo una obra que se lee como un laboratorio de posibles y encubiertas invenciones en tanta medida como una muy particular inflexión de autobiografía ensayístico-literaria. Se trata, por último, de un libro con el que se hace palpable el crecimiento emocional de una individualidad a la vez que se asiste a la educación sentimental de todo un tiempo histórico ya desaparecido o a punto de desaparecer y que, sin embargo, no dejará de perseverar en la memoria colectiva. Tomando el ejemplo de su maestro Gombrowicz, Piglia se pasó la vida informándonos del diario que se traía entre manos, dándonos a conocer extractos del mismo en diferentes momentos a través de conferencias o libros editados y asegurándose de recalcar que esa y no otra sería su verdadera obra, la que de alguna manera lo compondría y justificaría todo, de ahí que dedicara los que supo que eran los últimos años de vida a preparar prioritariamente, ciertos días de forma extenuante, la edición de esos diarios.

Lo que sorprende en los diarios de Piglia es el proyecto que proponen y desencadenan durante casi sesenta años de escritura. Como decimos, Piglia comienza a escribirlos, básicamente,

\footnotetext{
${ }^{34}$ En una entrada del año 1977, perteneciente al tercer volumen de los diarios de Renzi, leemos: "No poder escribir es el infierno [...] No confundir escribir con redactar" [2017:37].

${ }^{35}$ Antisentimentalidad que proviene, fundamentalmente, de los diarios de Pavese y de ese desposeído "anti-Gide" que es Gombrowicz en sus diarios, escritor de un soberbio dietario "en público" -con el que tenemos la sensación de asistir casi en directo a toda su vida en Buenos Aires-y que a la vez se distancia de todo. Escritor sin rentas ni propiedades territoriales, tal y como encomia Piglia, en el que "lo privado es un espacio de tensión con el mundo, centrado en una idea antisentimental de la vida personal. Mantenerse siempre a distancia, ser el observador de sí mismo y de los otros, no permitir nunca que nadie se acerque demasiado. Lo que Gombrowicz llama 'los sentimientos entre comillas'" [2016a:95].
} 
para decirse a sí mismo que es y será escritor ${ }^{36}$. En un principio, cuando es adolescente y durante los primeros años universitarios, quiere ser escritor para lograr impresionar al sexo opuesto, ganar seguridad en sus quehaceres, conocer las interioridades de un oficio que se le antoja poco menos que cinematográfico y, sin duda, también para contrariar a su padre ${ }^{37}$. Tras ello, pasados los primeros arrebatos de una agitada juventud en La Plata y Buenos Aires, cuando se han acumulado libros leídos con soltura en español, inglés, francés e italiano, cuando han abundado las conversaciones con intensas amistades que serían más tarde conocidos intelectuales, artistas o escritores, cuando florecen infinidad de proyectos editoriales o literarios y recibe cartas de autores consagrados como Sartre o Cortázar, cuando se hacen legión las pensiones, los bares, los cines que no cerraban nunca, las deambulaciones urbanas, los cuerpos femeninos y las tensiones políticas, cuando la lisonja y el reconocimiento acostumbran a llegar con sorpresiva facilidad ${ }^{38}$, casi con indómita frecuencia, cuando todo ello ha ocurrido, digo, Piglia quiere entonces ser escritor porque, básicamente, ha entrado en el secreto de que no se puede vivir sin escribir ni leer. Pues bien, la metáfora suprema de esta cotidiana necesidad vital viene avalada fundamentalmente por la construcción de los diarios renzianos.

Los diarios de Renzi son, de hecho, la prueba de que Piglia vivió para escribir porque pormenorizan como ninguna otra obra del autor la actividad que le empujó a desarrollar la conciencia de ser escritor. Como sabemos, Piglia estructura sus diarios como ocurridos a Emilio Renzi -ubicua constitución de sus figuraciones literarias-, hablando de este en tercera persona (a veces desde el propio Renzi, otras desde Piglia) y en combinación con la voz narradora de Renzi, en la primera persona que escribió el diario en tiempo real, viéndose de esta forma Piglia a sí mismo desde una mirada externa y levantando a menudo una sensación de ajenidad sobre su propia vida: todo lo que le pasaba a Piglia en su vida real era, en realidad, la novela de la vida de Emilio Renzi.

No pocas de las páginas de sus diarios se cuentan, sin duda, entre su mejor literatura, hablemos de ensayo o narración y, sin embargo, la mayor parte de ello no se publicó hasta el final de sus días. Cualquier accidente o azarosa coyuntura podría haber provocado que se perdieran esos

\footnotetext{
${ }^{36}$ En fecha 11/09/1967, Renzi define sus diarios como "[...] el proyecto de alguien que primero decide ser escritor y luego empieza a escribir, antes que nada, una serie de cuadernos en los que registra su fidelidad a esa posición imaginaria." [2015b:323].

${ }^{37}$ Cuando está a punto de aparecer La invasión (1967), Renzi se plantea en su diario, ante la tentación de separarse oficialmente de su padre, publicar sus libros con un "nombre falso" [2015b:328] -recordemos que así se titulará su recopilación de cuentos de 1975-. De aquí que Emilio Renzi -apellido de su madre, como sabemos- haya sin duda tenido tanta fortuna como alter ego de Piglia en buena parte de su producción narrativa.

${ }^{38}$ En fecha de 13 de febrero de 1967 escribe Renzi en su diario: "Siempre las cosas se me han dado con excesiva 'facilidad', parece que efectivamente hay una estrella que me protege, o la supersticiosa convicción de que siempre estaré a salvo." [2015b:291]. Otra breve muestra: el 8 de agosto de 1960 Renzi registra en su diario: "Estoy asombrado, la profesora de Introducción a la Literatura dijo en clase que mi trabajo sobre Martínez Estrada era lo mejor que había leído desde que está en la Facultad. Lo van a publicar en la revista de Humanidades." [ibid.,88].
} 
cuadernos de tapa negra en los que escribió desordenadamente sus diarios durante tantos años, sin guardar copia de ellos. Piglia no cede al inventario y ordenación de los mismos sino cuando se le diagnostica en 2013 la esclerosis lateral amiotrófica que no le permitirá -lo sabe entonces- vivir mucho más tiempo. Es decir, durante casi sesenta años Piglia sabe que está escribiendo lentamente una vida que quizá no llegue nunca a buen puerto, que quizá nadie pueda leer, y siendo la obra de su vida, con la que de forma más íntima y regular se volcó, sorpresivamente, Piglia parece ocuparse de ella siempre sin apuro ni claro plan de publicación, quizá porque en los años sesenta llega a escribir que sus diarios son una "impostura"39 o quizá porque realmente, para él, lo contado en esos diarios -removiendo con ello el estatuto formal del diario autobiográfico- no le ocurrió a él sino a Renzi. En cualquier caso, Piglia parece creer para sí, desde muy pronto, en un destino inexorable, albergando sobre este una fe poco menos que sacerdotal. El destino para él, como sabemos, consiste en devenir escritor y en escribir su diario de escritor interminablemente, con la serena intuición o supersticiosa confianza de que su diario -como en "La isla de Finnegan", en la que "las obras maestras duran lo que dura la lengua en la que fueron escritas" [2016a:228]- pervivirá, se leerá y durará -al menos- mientras dure la lengua en la que lo escribió.

Piglia es un factótum impuro de nuestra modernidad porque trató de abarcarlo casi todo a la vez que lo hizo de forma siempre híbrida, crítica o disidente. Su obsesión fue, en efecto, ser escritor pero no quiso ser ni estilísticamente los escritores que más admiraba -trató muy conscientemente de escapar de las alargadas sombras de Faulkner, Dostoievski, Borges o Sarmiento, como sabemos- ni nunca quiso plegarse a la biografía clásica del escritor consagrado -buscó siempre desentenderse de la pesadilla de tics y objetivos que se les supone o contagia a los grandes escritores-. Los otros elementos de su biografía que justifican su condición de "factótum impuro" pasan, desde luego, por su decisión personal de no estudiar literatura en la universidad -tomar el camino alternativo de estudiar Historia y no verse nunca como un escritor de ficción al uso, industrialmente profesionalizado ni formado en los cánones académicos-, por rechazar empleos relacionados con labores culturales o editoriales ${ }^{40}$ en su juventud -que si bien le ofrecían una estabilidad vital muy tentadora en momentos en los que estaba regularmente asediado por las estrecheces económicas, al mismo tiempo, le habrían impedido

\footnotetext{
39 "La suprema impostura está en el hecho mismo de escribir estos cuadernos. ¿Para quién los escribo? No creo que sea para mí y tampoco me gustaría que alguien los leyera." [2015b:58].

${ }^{40}$ Si bien, entre otras labores editoriales, Piglia trabajó como antólogo para la editorial Jorge Álvarez -comenzando con la ya citada publicación de Crónicas de Norteamérica (1967) en la famosa colección Crónicas a cargo de Julia Constenla desde 1965- o como director de la colección Serie Negra de la editorial Tiempo contemporáneo en 1969, etc.
} 
elegir sus horarios de escritura ${ }^{41}$-, por comenzar publicando fuera de Argentina ${ }^{42}$ pero, sobre todo, ya quedó dicho antes, por interesarse o mostrar debilidad hacia los escritores periféricos e igualmente impuros por espíritu, acción o ambos³; ${ }^{43}$ esto es, por los escritores que escribieron y vivieron lejos de los grandes circuitos académicos, comerciales o institucionales ${ }^{44}$ o por los escritores que, aun siendo relativamente reconocidos en vida, describen movimientos vitales y literarios impuros, insumisos de la tradición, conflictivos, alejados de los días armoniosos y las sociedades felices.

Por otra parte, la atracción de Piglia por lo descarrilado, lo excéntrico, lo antiburgués o lo políticamente incorrecto provendría, entre otros, de su anarquismo espiritual y formación marxista, de su atracción por la mirada forastera o extranjera, de los ejercicios de funambulismo viviendo entre dos ciudades, distintas amantes y diversas interacciones lingüísticas, del hecho de sentirse cerca del temperamento de Borges, que es invitado a dar una conferencia o entrevista y pasma a todo el mundo con sus corteses provocaciones apenas ha empezado a hablar; incluso de sus amistades inmersas en el activismo político o el hampa, como ocurre con el ladrón de guante blanco Cacho Carpatos, el amigo outsider tan presente en el primer volumen de los diarios de Renzi y con el que estuvo a punto de matarse en varios accidentes de tráfico en los años sesenta ${ }^{45}$. Y todo este mundo impuro está

41 "Durante toda mi vida dejé todo de lado por la literatura, elegí la intemperie para preservar la libertad de trabajo", se dice Renzi en sus diarios en 1977 [2017:34].

${ }^{42} \mathrm{Si}$ bien es cierto que publicar en Casa de las Américas en los años 60 -fue el caso de Jaulario (1967)- no suponía hacerlo precisamente en un lugar secundario o excéntrico, máxime si se tiene en cuenta que este primer libro de Piglia aparece reeditado, con "variantes de importancia" [Mesa Gancedo 2006:169], pocos meses después -como ya dijimos antes- bajo el título La invasión (1967) y en la connotada editorial argentina Jorge Álvarez.

${ }^{43}$ Marbete en el cual podrían caber, por ejemplo, los tres escritores bajo cuya indudable sombra Piglia da forma a sus diarios: Gombrowicz, Kafka y Pavese. Aunque Renzi habla en sus diarios de los dietarios, entre otros, de Gide, Musil, Stendhal, Brecht o Tolstoi, Renzi confiesa en 1966 que, en última instancia, para él solo valen los diarios "escritos contra uno mismo" [2016e:66], es decir, los diarios de Kafka y Pavese. Sobre los diarios de Pavese añade, incluso, en 1968, que se trata de un libro que nunca ha podido "soltar" [ibid.,53].

${ }_{44}$ Macedonio o Arlt, pongamos por caso. Tres reflexiones de Renzi en sus diarios que podrían ilustrar la cuestión son las siguientes; en la primera, de 1966, leemos: "[...] lo que más me interesa es construir una figura que se aleje de los estereotipos argentinos del 'escritor'" [2015b:243]. En la segunda, escrita cuando aparece publicada la primera obra de Piglia en Argentina -La invasión (1967)-, Renzi se dice que, en ese preciso momento, todo lo que él debía hacer era "tratar de no convertirse en un 'escritor'" [ibid.,330]. Por último, en 1969, refiriéndose Renzi a Manuel Puig como ejemplo de escritor que, aun siéndolo profesionalmente, no lo parece en absoluto y ahí radica su virtud, leemos: "Es un novelista profesional, el primero que conozco y está decidido a vivir de su literatura. Nadie que yo recuerde tenía ese proyecto entre nosotros desde los tiempos de Manuel Gálvez. [...] uno lo ve y no parece un escritor, y ése es su mérito porque es más escritor que cualquier de los farsantes que representan ese papel" [2016e:136].

${ }^{45}$ Piglia siempre observó a la policía y a toda fuerza de orden con recelo. En una anotación de su diario en la que utiliza el plural mayestático podemos leer: "Desde siempre hemos desconfiado de la policía y siempre nos hemos considerado infractores de la ley (no importa cuál), de modo que cualquier cruce con alguien uniformado se convierte en una escena compleja" [2015b:326].Y ello ocurre no solo, por ejemplo, a causa de su gusto por la literatura arltiana, por la incursión de su narrativa en el mundo del hampa o por las consecuencias de la dictadura argentina que sufrió en carne propia durante su juventud sino porque Piglia siempre se sintió más cerca del lado contestatario, revolucionario y marginal. Añadamos que es curioso observar, v. gr., cómo ante una primera oferta de trabajo que en calidad de profesor universitario en EE.UU. le llega a Piglia en 1976, Renzi escribe en su diario: "Mi pasaporte venció el 5 de diciembre, hay que renovarlo, pedir la visa, miedo a las identificaciones" [2017: 32]. 
completamente expuesto, cual escaparate de una tienda en un cuadro de Hopper, en los diarios de Renzi. Además, como vimos al comienzo de este trabajo, Piglia cree en el tipo de vida y, sobre todo, en el tipo de escritura que duerme con las maletas hechas: el desprendimiento y la frialdad (de ser necesaria), lo provisional y efímero, la alteridad y la libertad de poder fugarse en cualquier momento o el hecho de vivir tentado por el comienzo ininterrumpido, todo ello funciona siempre en Piglia como mojón ético y moral: "[...] se conoce la vieja superstición que me acompaña desde siempre: los comienzos exactos que permiten empezar de nuevo. El que se va ('Wakefield') y deja todo para convertirse en 'el otro'" [2017:76], escribe Renzi en su diario el primer día de marzo de $1976^{46}$.

Otro aspecto no menor percibido en la lectura de los diarios de Renzi es que estos confirman y clausuran una trayectoria literaria construida durante sesenta años en función de una serie de claves muy reconocibles. Entre estas claves destaca la siguiente: la literatura de Piglia se activa temática y sustancialmente sobre la memoria personal y familiar ${ }^{47}$ a la vez que su engranaje interior se mueve montado sobre una noción estilística que privilegia los modos de narrar ensayístico-periodísticos. En relación a este último punto, por ejemplo, Renzi anota en su diario cuánto le había gustado que, en sus primeros días en la universidad, en abril de 1960, el profesor Enrique Barba lanzara esta opinión a sus estudiantes: "Cualquier libro de historia que no tenga cinco notas al pie por página [...] es una novela" [2015b:70]. Pocos meses más tarde, y tras haber estado escuchando un partido de fútbol en la radio, consignará Renzi: "Me interesa el hecho de que la narración está acompañada por los 'comentarios', es decir, la explicación teórica de lo que sucede en el juego. El relato y el concepto que lo define vienen juntos." [ibid.,95]. Finalmente, en 1967, mientras Renzi se trae un proyecto de novela entre manos, se dice que debe regresar a la novela de acción, cercana a las tendencias antirrománticas que conviertan la historia en tema de investigación y de encuestas periodísticas, cifrando su más alta ambición literaria en el hecho de que -como ocurriera con el Pierre Menard de Borges- "los primeros críticos reseñaran la novela como un libro de no ficción." [ibid.,283].

\footnotetext{
${ }^{46}$ Apenas unas semanas después, el 24 de marzo de 1976, se llevaría a cabo la Operación Aries, es decir, el golpe de Estado de Videla.

${ }^{47}$ Piglia ambicionó siempre escribir una novela sobre su familia. En fecha 22/09/1971 escribe Renzi en su diario: "Vuelvo a la idea de escribir una novela familiar a partir de los relatos y los mitos que circulan en mi casa. Muchos personajes y muchos argumentos, tengo que encontrar un tono irónico para contar esa épica. [...] Quizá tengo que dejar todo lo que estoy haciendo y escribir la saga familiar, que es mía y cuyas historias conozco mejor que nadie." [2016e:271]. Aquella ambición de Piglia (que de su carnet de identidad como Ricardo Emilio Piglia Renzi pasa a Emilio Renzi en su literatura) estaba, por lo demás, centralizada en la figura de su abuelo Emilio Renzi, el cual hablaba, arrastrando toda una serie de visibles traumas de su experiencia bélica en la I Guerra Mundial, "como si continuamente se tradujera de una lengua olvidada" [2015b:105]. Sobre su familia y su escritura, por último, escribe Renzi: "En la literatura, creo, lo fundamental es tener un mundo propio. En mi caso, ese material es secretamente autobiográfico y depende de la multitud de historias familiares que he ido escuchando a lo largo de mi vida. De modo que la novela trabaja a partir de una realidad ya narrada y el narrador trata de recordar y de reconstruir las vidas, las catástrofes, las experiencias que ha vivido y le han contado (vivido y contado para mí es lo mismo)." [ibid.,154].
} 
Digamos, para terminar, que los diarios de Renzi cierran -reparan- el agujero abruptamente abierto la noche de 1957 en la que los Piglia-Renzi cargan furtivamente sus muebles en un camión y salen de madrugada, por motivos políticos relacionados con su padre -médico y peronista convencido-, desde Adrogué a Mar del Plata. El diario de Renzi empezó a existir aquella madrugada en la mente de Piglia y cuando se despertó, el diario todavía estaba allí. El diario cumplió su destino, se llevó a cabo como debía y al publicarse dio más lustre todavía a un escritor que no lo necesitaba. Aunque hubo momentos para el desánimo, para sentirse deprimido, fraudulento y fracasado, Piglia se caracterizó gran parte del tiempo de su vida por sentirse un tipo con estrella -y quizá por eso le interesaron siempre, en general, los tipos sin estrella-. Lo que el futuro entregó a Piglia terminó mostrándole, a él y al diario de Renzi, que ninguno de los dos se equivocaba cuando dijeron a la par en noviembre y diciembre de 1977:

\footnotetext{
A veces una rara sensación de destino favorable lo seguía; había llegado a creer que le alcanzaba con desear algo para tenerlo. Eso fortalecía la duplicidad de su vida y el secreto con el que vivía esa certidumbre con sus aires benéficos. En cuanto a la desdicha, parecía venir de otro, como si alguien se ocupara de vivir por él. [...] tengo una especie de confianza ciega sobre un futuro en el que alcanzaré lo que busco (aunque no sé muy bien qué es eso). El presente se presenta mal, y el futuro próximo también, pero los años últimos serán los que harán lugar a esas viejas esperanzas. Extraña mitología personal [2017:42,59].
}

Los ensayos y los diarios de Piglia fueron, en fin, la obra en la que cupo (casi) todo y en la que está (casi) toda esa inseparable dualidad Piglia-Renzi -si incluimos, además, los cuentos y las novelas del autor-: el más despierto y el más inspirado, el más libérrimo y azaroso, el atormentado y el feliz, el vulnerable, orgulloso y calculador, el más preocupado -y preparado- para la posteridad, el fetichista literario y el que vivió por y en los libros, el más obsesivamente escritor y el más infinito lector, todos los Piglia posibles, comparecen en su escritura ensayística y, finalmente, en los diarios de Renzi, para despedirse de la vida casi exactamente como él siempre lo previó.

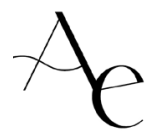




\section{BIBLIOGRAFÍA}

BORGES, Jorge Luis, "La supersticiosa ética del lector", Azul, año 2, no 8, enero-febrero, 1931, 11-14.

—_ "El escritor argentino y la tradición", Discusión. Emecé, Buenos Aires, 1957.

BRATOSEVICH, Nicolás, y Grupo de Estudio, Ricardo Piglia y la Cultura de la Contravención, San José, Atuel, 1997.

CALINESCU, Matei, Cinco caras de la Modernidad. Modernismo, vanguardia, decadencia, kitsch, postmodernismo, Madrid, Tecnos/Alianza, 2003.

CARDWELL, Richard A. y McGuirk, Bernard (eds.), ¿Qué es modernismo? Nueva Encuesta, nuevas lecturas, Boulder, University of Colorado, 1993.

CARRIÓN, Jorge (ed.), El lugar de Piglia. Crítica sin ficción, Barcelona, Candaya, 2008.

CERVANTES, Miguel de, Don Quijote de la Mancha, Barcelona, Galaxia Gutenberg / Círculo de Lectores, 2004.

CORBATTA, Jorgelina, Narrativas de la guerra sucia en Argentina: Piglia, Saer, Buenos Aires, Corregidor, 1999.

DE MARÍA, Laura, Argentina: Ricardo Piglia dialoga con la Generación del 37, Buenos Aires, Corregidor, 1999.

DE TORO, Alfonso (ed.), Jorge Luis Borges: Translación e Historia, Tubinga, OLMS Verlag, 2010.

CORRAL, Rose (ed.), Entre ficción y reflexión: Juan José Saer y Ricardo Piglia, México, El Colegio de México, 2007.

FORNET, Jorge (al cuidado de), Ricardo Piglia, La Habana, Casa de las Américas, 2000.

, El escritor y la tradición: en torno a la poética de Ricardo Piglia, Letras Cubanas, Colombia, 2005.

— El escritor y la tradición, Ricardo Piglia y la literatura argentina, Buenos Aires, Fondo de Cultura Económica, 2007.

GIORdANO, Alberto, Modos del ensayo. De Borges a Piglia, Rosario, Beatriz Viterbo, 2005.

GOMBROWICZ, Witold, Diario (1953-1969), Barcelona, Seix Barral, 2011.

GONZÁlEZ ÁlVAREZ, José Manuel, En los "bordes fluidos". Formas híbridas y autoficción en la escritura de Ricardo Piglia, Berna, Peter Lang, 2009.

GONZÁLEZ SAWCZUK, Susana Ynés, Ficción y crítica en la obra de Ricardo Piglia, Medellín, La Carreta Literaria, 2008. 
GRACIA, Jordi y Ródenas, Domingo, Historia de la literatura española (7). Derrota y restitución de la modernidad (1939-2010), José-Carlos Mainer (dir.), Madrid, Crítica, 2011.

HABERMAS, Jürgen, The Philosophical Discourse of Modernity, Cambridge, MIT, 1992.

JAUSS, Hans Robert, Las transformaciones de lo moderno. Estudios sobre las etapas de la modernidad estética, Madrid, Visor, 1995.

KAFKA, Franz, Obras completas II. Diarios. Carta al padre, Barcelona, Galaxia Gutenberg / Círculo de Lectores, 1999.

MESA GANCEDO, Daniel (coord.), Ricardo Piglia: la escritura y el arte nuevo de la sospecha, Sevilla, Universidad de Sevilla, 2006.

MESCHONNIC, Henri, Poétique du traduire, París, Verdier, 1999.

NAVAJAS, Gonzalo, La modernidad como crisis. Los clásicos modernos ante el siglo XXI, Madrid, Biblioteca Nueva, 2004.

ORECCHIA HAVAS, Teresa, Asedios a la obra de Ricardo Piglia, Berna, Peter Lang, 2010. (ed.) Homenaje a Ricardo Piglia, Buenos Aires, Catálogos, 2012.

PASTORMERLO, Sergio, Borges crítico, Buenos Aires, Fondo de Cultura Económica, 2007.

—_, "Borges, el Quijote y los cervantistas españoles", Olivar, La Plata, v. 7, n. 7, 119-124, jun. 2006.

PEREIRA, María Antonieta, Ricardo Piglia y sus precursores, Buenos Aires, Corregidor, 2001.

PIGLIA, Ricardo, Antología personal, México, Fondo de Cultura Económica, 2016a.

—_, "Borges y Gombrowicz", Espacios de crítica y producción, 6. 1987, 13-15.

—_, Crítica y ficción, Buenos Aires, Siglo Veinte, 1989; Buenos Aires, Seix Barral, 2000; Barcelona, Anagrama, 2001;

—_ El último lector, Barcelona, Anagrama, 2005.

— Escritores norteamericanos, Buenos Aires, Tenemos las máquinas, $2016 \mathrm{~b}$.

—, Formas breves, Barcelona, Anagrama, 2015a.

—_, La forma inicial. Conversaciones en Princeton, San José, Lanzallamas, 2016c.

—_ La invasión, Buenos Aires, Jorge Álvarez, 1967.

—, Las tres vanguardias. Saer, Puig, Walsh, Buenos Aires, Eterna Cadencia, $2016 \mathrm{~d}$.

— Los diarios de Emilio Renzi. Años de formación, Barcelona, Anagrama, $2015 b$.

— Los diarios de Emilio Renzi. Los años felices, Barcelona, Anagrama, 2016e.

— Los diarios de Emilio Renzi. Un día en la vida, Barcelona, Anagrama, 2017. 
—, Nombre falso, Buenos, Aires, Siglo XXI, 1975.

—_ Prisión perpetua, Buenos Aires, Seix Barral, 1998.

QUINTANA, Isabel, Figuras de la experiencia en el fin de siglo. Cristina Peri Rossi, Ricardo Piglia, Silviano Santiago, Juan Jose Saer, Rosario, Beatriz Viterbo, 2001.

RANCIÈRE, Jacques, El reparto de lo sensible. Estética y política, Santiago, LOM ediciones, 2009.

RODRÍGUEZ PÉRSICO, Adriana (comp.), Ricardo Piglia: una poética sin límites, Instituto Internacional de Literatura Iberoamericana, Pittsburgh, Universidad de Pittsburgh, 2004.

—_, "Los diarios de Emilio Renzi o el pudor autobiográfico", Zama / 9. 2017, 59-69.

ROMERO, Julia, G., (ed.), Las máquinas ficcionales de Ricardo Piglia, Buenos Aires, Corregidor, 2015. 